\title{
ESTIMATED DEMAND OF BIO PESTICIDES IN INDIA-A VIVID PICTURE
}

\author{
Dr.V.Gurumoorthy \\ Senior fellow-ICSSR \\ Madras Institute of Development Studies
}

Chennai

Article DOI: https://doi.org/10.36713/epra5476

\begin{abstract}
Bio pesticides are pesticides which are formed by using natural materials like plants, animals and its excreta, bacteria and minerals. Bio pesticides are often used in Integrated Pest Management(IPM) also. Conventional pesticides, on the other hand, use synthetic materials to control pests. However, due to increased awareness about the detrimental effects of conventional pesticides, the demand for bio pesticides has been steadily increasing. With the organic farming being an influential factor in the current farming setup, bio pesticides play a significant role in the entire organic inputs sector. Bio pesticides are need of the hour due to increase in pest resistance and yield. The global biopesticides market size is projected to grow at a CAGR of 14.7\% from an estimated billion value of USD 4.3 billion in 2020 to reach USD 8.5 billion by 2025. Thus, the growing organic products market has made a considerable impact in the demand for bio pesticides. Against this backdrop, the present study is taken up to analyse the estimated demand of bio pesticides in India.
\end{abstract}

KEY WORDS: Bio pesticides, demand

\section{INTRODUCTION}

Bio pesticides are pesticides which are formed by using natural materials like plants, animals and its excreta, bacteria and minerals. Bio pesticides are often used in Integrated Pest Management(IPM) also. Conventional pesticides, on the other hand, use synthetic materials to control pests. However, due to increased awareness about the detrimental effects of conventional pesticides, the demand for bio pesticides has been steadily increasing. With the organic farming being an influential factor in the current farming setup, bio pesticides play a significant role in the entire organic inputs sector. The threat that the conventional pesticides pose among humans, animals and nature has long been debated and bio pesticides have emerged as the solution. Sustainable solutions like Bio pesticides are need of the hour due to increase in pest resistance and yield. The global biopesticides market size is projected to grow at a CAGR of $14.7 \%$ from an estimated billion value of USD 4.3 billion in 2020 to reach USD 8.5 billion by 2025 . Thus, the growing organic products market has made a considerable impact in the demand for bio pesticides. Against this backdrop, the present study is taken up to analyse the estimated demand of bio pesticides in India.

\section{OBJECTIVES OF THE STUDY}

$>$ To depict the estimated demand of bio pesticides in India

$>$ To analyse the estimated demand of bio pesticides with appropriate statistical tools

\section{SCOPE OF THE STUDY}

The scope of the study is restricted to the estimated demand of bio pesticides in India. The estimated demand for bio pesticides in various states and union territories in India, for the period from 2014-2019 have been collected and analyzed by adopting various statistical tools.

\section{METHODOLOGY}

This paper is based on Secondary data sourced from annual reports and other published sources.

\section{TOOLS FOR ANALYSIS}

Descriptive statistics have been employed to analyse the data and inferences were drawn.

The following table shows the estimated demand of bio pesticides in various states in India. 
ISSN (Online): 2455-3662

EPRA International Journal of Multidisciplinary Research (IJMR) - Peer Reviewed Journal

Volume: 6 | Issue: 10 | October 2020 || Journal DOI: 10.36713/epra2013 || SJIF Impact Factor: 7.032 ||ISI Value: 1.188

TABLE:1.1

ESTIMATED DEMAND OF BIO-PESTICIDES IN VARIOUS STATES DURING 2014-15 T0 2018-19 As on 28.11.2019 Unit: M.T. Technical Grade

\begin{tabular}{|c|c|c|c|c|c|c|}
\hline S. No. & $\begin{array}{c}\text { States/U } \\
\text { Ts } \\
\end{array}$ & 2014-15 & 2015-16 & 2016-17 & 2017-18 & 2018-19 \\
\hline 1 & Andhra Pradesh & 55 & 30 & 40 & 45 & 48 \\
\hline 2 & Bihar & 278 & 320 & 364 & 370 & 461 \\
\hline 3 & Chhattisgarh & $N R$ & $N R$ & $N R$ & $N R$ & $N R$ \\
\hline 4 & Goa & 13 & 22 & $N R$ & 4 & $N R$ \\
\hline 5 & Gujarat & 297 & 295 & 327 & 323 & 330 \\
\hline 6 & Haryana & 350 & 360 & 400 & 400 & 420 \\
\hline 7 & Himachal Pradesh & 40 & 20 & 2 & 1.45 & 2 \\
\hline 8 & Jharkhand & 3 & 3 & 11 & 50 & 54 \\
\hline 9 & Karnataka & 580 & 630 & 630 & 630 & 630 \\
\hline 10 & Kerala & 473 & 473 & 667 & 729 & 789 \\
\hline 11 & Madhya Pradesh & 302 & 413 & 1193 & 365 & 372 \\
\hline 12 & Maharashtra & 3876 & 4353 & 4353 & 3957 & 3957 \\
\hline 13 & Orissa & 315 & 315 & 315 & 315 & 315 \\
\hline 14 & Punjab & 138 & 138 & 126 & 278 & 284 \\
\hline 15 & Rajasthan & 18 & 19 & 19 & 19 & 19 \\
\hline 16 & Tamil Nadu & 197 & 282 & 298 & 936 & 555 \\
\hline 17 & Telangana & 75 & 75 & $N R$ & 92 & 101 \\
\hline 18 & Uttar Pradesh & 43 & 45 & 47 & 47 & 47 \\
\hline 19 & Uttaranchal & 38 & 43 & 47 & 60 & 81 \\
\hline 20 & West Bengal & 1200 & 1100 & 1265 & 1265 & 1265 \\
\hline & SubTotal & 8290 & 8938 & 10105 & 9887 & 9418 \\
\hline \multicolumn{7}{|c|}{ North-Eastern } \\
\hline 21 & Arunachal Pradesh & $N R$ & $N R$ & $N R$ & $N R$ & 17 \\
\hline 22 & Assam & 180 & $N R$ & $N R$ & 217 & 234 \\
\hline 23 & Manipur & 1 & 1 & $N R$ & 1.20 & $N R$ \\
\hline 24 & Meghalaya & 15 & $N R$ & 23 & $N R$ & $N R$ \\
\hline 25 & Mizoram & $N R$ & $N R$ & $N R$ & $N R$ & $N R$ \\
\hline 26 & Nagaland & 22 & 24 & 24 & 25 & 26 \\
\hline 27 & Sikkim & $N R$ & $N R$ & $N R$ & $N R$ & $N R$ \\
\hline 28 & Tripura & 266 & 235 & 279 & 262 & $N R$ \\
\hline & SubTotal & 484 & 260 & 326 & 505 & 277 \\
\hline \multicolumn{7}{|c|}{ Union Territories } \\
\hline 29 & Andaman \& Nicobar & 0.75 & $N R$ & $N R$ & $N R$ & $N R$ \\
\hline 30 & Chandigarh & $N R$ & $N R$ & $N R$ & $N R$ & $N R$ \\
\hline 31 & Dadra \& Nagar Haveli & $N R$ & $N R$ & $N R$ & $N R$ & $N R$ \\
\hline 32 & Daman \& Diu & $N R$ & $N R$ & $N R$ & $N R$ & $N R$ \\
\hline 33 & Delhi & $N R$ & $N R$ & $N R$ & $N R$ & 15 \\
\hline 34 & Jammu \& Kashmir & 1 & 1 & 2 & 2 & 2 \\
\hline 35 & Ladakh & $N R$ & $N R$ & $N R$ & $N R$ & $N R$ \\
\hline 36 & Lakshadweep & $N R$ & $N R$ & $N R$ & $N R$ & $N R$ \\
\hline 37 & Pondicherry & 20 & 33 & 16 & 17 & 16 \\
\hline & SubTotal & 21 & 33 & 16 & 17 & 31 \\
\hline & Grand Total & 8795 & 9230 & 10447 & 10409 & 9725 \\
\hline
\end{tabular}

Source: States/UTs Zonal Conferences on Inputs of Plant Protection during Kharif \& Rabi Seasons. NR : Not reported by States/UTs 
It can be seen that apart from Nagaland, no other North-Eastern states have registered continuous demand in the years. The same scenario can be seen in Union Territories as well, Pondicherry and Jammu and Kashmir have registered continuous demand.
Telangana and Goa have exhibited irregular trend, wheras Chattisgarh has not shown any demand for bio pesticides in the given years. In the state of Tamil $\mathrm{Nadu}$, the demand shows an increasing trend except in the year 2018-19.

TABLE:1.2

\section{Descriptive Statistics}

\begin{tabular}{|c|c|c|c|c|c|c|}
\hline & & 2014-15 & $2015-16$ & $2016-17$ & 2017-18 & 2018-19 \\
\hline \multirow[t]{2}{*}{$\mathrm{N}$} & $\mid$ Valid & 21 & 21 & 21 & 21 & 21 \\
\hline & Missing & $\overline{0}$ & 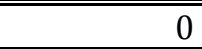 & 0 & 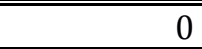 & 0 \\
\hline \multicolumn{2}{|c|}{ Mean } & 396.24 & 427.24 & 486.71 & 472.69 & 465.43 \\
\hline \multicolumn{2}{|c|}{ Median } & 138.00 & 138.00 & 126.00 & 278.00 & 284.00 \\
\hline \multicolumn{2}{|c|}{ Mode } & $1^{\mathrm{a}}$ & $1^{\mathrm{a}}$ & $2^{\mathrm{a}}$ & $1^{\mathrm{a}}$ & $\overline{2}$ \\
\hline \multicolumn{2}{|c|}{ Std. Deviation } & 844.910 & 939.316 & 960.611 & 868.949 & 862.496 \\
\hline \multicolumn{2}{|c|}{ Variance } & 713872.190 & 882313.990 & 9292773.014 & 7555071.918 & 7473899.957 \\
\hline \multicolumn{2}{|c|}{$\begin{array}{l}\text { Skewness } \\
\end{array}$} & 3.861 & 4.011 & 3.590 & 3.542 & 3.645 \\
\hline \multicolumn{2}{|c|}{ Std. Error of Skewness } & ב.501 & ב.501 & .501 & .501 & .501 \\
\hline \multicolumn{2}{|c|}{ Kurtosis } & 16.005 & 17.140 & 14.302 & 14.050 & 1014.724 \\
\hline \multicolumn{2}{|c|}{ Std. Error of Kurtosis } & ב.972 & .972 & .972 & .972 & .972 \\
\hline
\end{tabular}

The above table exhibits the computed data of descriptive statistics for the states that have registered continuous demand; as such 21 states have been included for the study. The mean value of the estimated demand for bio pesticides have been increasing in the given years. A low standard deviation can be seen in major years, which indicates close association to mean. Other descriptive statistics like skewness, kurtosis can also been seen.

\section{CONCLUSION}

The growing demand scenario is well observed in majority of the states. This demand is an indicator of paradigm shift in the farming scenario. An increased share of bio pesticides in the pesticides market can be seen in the analyzed data. The increase in demand is met out by the supply, which balances the same. Thus, a new era has been ushered in, with the growing realization about organic inputs in general and bio pesticides in particular. With effective marketing strategy, bio pesticides are sure to emerge as an effective alternate to the conventional pesticides in the near future. A promising trend shows that due to increased awareness about sustainable solutions to conventional farming, chemical pesticides might get replaced with bio pesticides very soon. It is high time the policy makers take principled stand towards increasing the subsidies and incentives of bio pesticides, which will enhance both the production and marketing of the bio pesticides sector.

\section{REFERENCES}

1. https://www.globenewswire.com

2. https://www.marketsandmarkets.com

3. https://www.prnewswire.com

4. https://www.greenbook.org 